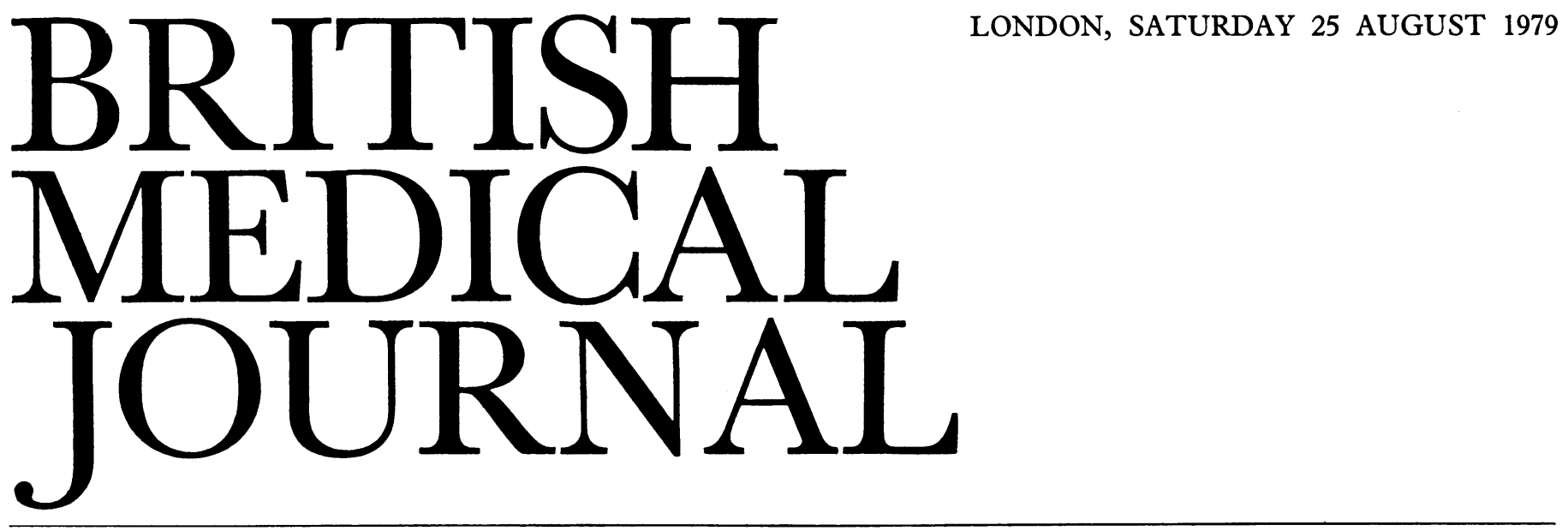

\title{
Respiratory syncytial virus: a community problem
}

Each winter the admissions of children to hospital for respiratory disease are dominated by infections with respiratory syncytial virus-most often bronchiolitis, less commonly pneumonia or croup. ${ }^{1-4}$ Its importance in hospital patients is well recognised, but we know much less about the epidemiological pattern of infections with the virus in the community. Prospective studies in the general population are never easy, but several such investigations into respiratory syncytial virus infections have been undertaken in the United States. The results are important for attempts at controlling infections with this virus.

In Britain respiratory syncytial virus causes an epidemic during the winter months every year. ${ }^{45}$ On average these outbreaks last for four months with the peak incidence of infection in February or March. The appearance of the virus coincides with the fall in temperature in the winter, and when the temperature rises in the spring the infections decrease. ${ }^{5}$ The risk of severe infections is much higher in urban-and especially industrial-populations than in rural communities, ${ }^{3}$ and is increased where there is overcrowding, poor housing, unemployment, and a high proportion of children in the community. ${ }^{6}$ Not surprisingly, the risk of hospital admission is also higher in children in lower social classes. ${ }^{3}$ The much publicised outbreak of fatal infection in infants in Naples last winter was probably at least partly due to respiratory syncytial virus in conditions of severe social deprivation. ${ }^{7}$

The impact of respiratory syncytial virus on the community as a whole has emerged clearly from surveillance programmes in the United States. ${ }^{8-11}$ These were long-term studies of families with young children, and included laboratory confirmation of infection by virus isolation and serological tests. The most striking result was the high incidence of infection in the general population during epidemics. Within the families studied the overall attack rate-including adultsvaried between $12^{\circ}{ }_{0}$ and $21^{\circ}{ }_{0} \cdot{ }^{9-11}$ Infection seemed usually to be introduced into a family by an older child, ${ }^{8}{ }^{10}$ and the attack rate in members of infected families was about $50 \% .1011 \mathrm{In}$ infants under 1 year old, this rate rose to $60 \%{ }^{1011}$ Most people infected had symptoms, mainly confined to the upper respiratory tract, and there was tendency for respiratory syncytial virus infections to restrict activity more than those due to other viruses. As might be expected, infections tended to be more severe in infants than in older children, and lower respiratory tract disease such as bronchiolitis, pneumonia, and croup were diagnosed more often in infants. ${ }^{10-12}$ In one study in Tecumseh, Michigan, ${ }^{9}$ however, hospital admissions for these diseases did not increase during epidemics of respiratory syncytial virus infection-possibly reflecting an impact of the virus on a small town with a population of 10000 that is different from that on an industrial city. Indeed, the collaborative study carried out for the Medical Research Council in Britain showed that infants in industrial areas had a 1 in 40 chance of being admitted to hospital with severe infections with the virus during their first three months of life. ${ }^{3}$

The American surveillance studies also showed that some of the infections in older children and adults were reinfections. ${ }^{10}$ In a longitudinal study of young children in North Carolina Henderson et al ${ }^{12}$ found that in the years of major epidemics $75 \%$ of those exposed to the virus for the second time became infected and $65 \%$ of those after a third exposure. Virtually all infants became infected when they first encountered the virus. The attack rates were much lower in years when the virus did not cause a major epidemic. Despite the frequency of reinfection, the attack rate did fall with successive exposures and this was accompanied by a progressive decrease in the severity of the disease, showing that there was some measure of immunity-albeit slight-after infection with the virus. Neutralising antibody developed after both primary infections and reinfections, and antibody declined less after the second than after the first infection. The apparently low level of immunity does not, therefore, seem to be due to lack of a humoral immune response.

If generally true, these results have serious implications for our attempts to control the virus by vaccination. Theoretically this should not be difficult, since there is only one virus serotype, but attempts to immunise young children with an inactivated virus vaccine have failed to give protection. ${ }^{13-16}$ In fact, the incidence of severe disease was higher in those vaccinated than in unvaccinated controls. In any event, vaccine-induced immunity is unlikely to give good protection when naturally acquired infection fails to do so. Clearly, control of respiratory syncytial virus is going to be complex and difficult.

1 Sandiford, B R, and Spencer, B, British Medical fournal, 1962, 2, 881.

${ }^{2}$ Gardner, P S, Elderkin, F M, and Wall, A H, British Medical Fournal, $1964,2,1570$.

${ }^{3}$ Report to the Medical Research Council Subcommittee on Respiratory Syncytial Virus Vaccines, British Medical fournal, 1978, 2, 796. 
${ }^{4} \mathrm{Kim}, \mathrm{H}$ W, et al, American Journal of Epidemiology, 1973, 98, 216.

${ }^{5}$ Martin, A J, Gardner, P S, and McQuillan, J, Lancet, 1978, 2, 1035.

${ }^{6}$ Sims, D G, et al, British Medical fournal, 1976, 2, 1095.

7 Observer Magazine, 15 April 1979, p 62.

${ }^{8}$ Monto, A S, and Cavallaro, J J, American fournal of Epidemiology, 1971, 94, 280.

9 Monto, A S, and Lim, S K, American fournal of Epidemiology, 1971, 94, 290.

10 Cooney, M K, Fox, J P, and Hall, C E, American fournal of Epidemiology, $1975,101,532$

11 Hall, C B, et al, New England fournal of Medicine, 1976, 294, 414

${ }^{12}$ Henderson, F W, et al, New England fournal of Medicine, 1979, 300, 530.

${ }^{13}$ Kapikian, A Z, et al, American Fournal of Epidemiology, 1969, 89, 405

$14 \mathrm{Kim}, \mathrm{H}$ W, et al, American fournal of Epidemiology, 1969, 89, 422.

15 Fulginiti, V A, et al, American fournal of Epidemiology, 1969, 89, 435.

${ }^{16}$ Chin, J, et al, American fournal of Epidemiology, 1969, 89, 449.

\section{Artificial insemination for all?}

Artificial insemination by donor (AID) is available (mostly semiprivately) in some 22 centres in Britain, of which seven are in London. In 1976 (the most recent year for reliable figures) at least 700 pregnancies were achieved by AID. Nevertheless, the distribution of centres providing the service is uneven-for example, there is none in the south or northeast of England or in Wales. The AID subcommittee of the Royal College of Obstetricians and Gynaecologists has called for new facilities to be set up to meet "a substantial and growing demand for AID," and has produced a booklet ${ }^{1}$ for patients seeking advice about the treatment. The booklet, funded by the DHSS, gives succinct advice on such matters as confidentiality (which must be absolute), complications of pregnancy (the incidence of which is normal), and legitimacy (which remains a confused question, though the booklet advises that "babies born within a marriage are presumed to be legitimate"). If a couple decide to go ahead with AID, what problems can they expect, and what are the prospects for success?

The indication for AID (usually gross male subfertility or familial disease) must be carefully checked. All women undergoing AID should first be investigated to rule out any obvious bar to fertility, ${ }^{2}$ but even then AID is no guarantee of conception. In recent published series the proportion of women who conceived has varied from $37 \%$ to $71 \%$ when frozen semen was used, ${ }^{4-7}$ and from $42 \%$ to $84 \%$ with fresh semen. ${ }^{8-12}$ (One report ${ }^{13}$ from California gave a conception rate of $94 \%$ when clomiphene was used to induce ovulation: 17 women had 15 full-term pregnancies, including two sets of twins.) About half the patients who conceive do so within three cycles of starting treatment. ${ }^{8912}$ The side effects of treatment are few: gonorrhoea is one risk, but screening is possible even when fresh semen is used ${ }^{14}$ and is easier still with frozen semen.

The debate about the ethics of $\mathrm{AID}^{15-17}$ seems now to have been resolved, but one aspect of the treatment that should not be ignored is the psychological problems ${ }^{811}$ that may occur in couples. Apparently unsuitable cases, ${ }^{3}$ such as patients with unstable marriages, are usually refused treatment. Nevertheless, in some series ${ }^{7}$ up to half of patients defaulted during six months of treatment, and couples should, perhaps, be offered better psychological support during a course of AID. ${ }^{7}$ In some circumstances help given to a couple to accept and enjoy their childlessness may be preferable to helping persistence with a treatment that makes them uneasy.
Follow-up studies ${ }^{12}$ after successful pregnancy with AID are few, but we have no evidence that the incidence of marital breakdown rises. There is little information on the long-term welfare of the children. ${ }^{15}$

The source of semen remains a problem. Most centres still use the long-suffering medical undergraduate, although four years ago we drew attention ${ }^{18}$ to disquiet among clinical deans over this practice. There is no consensus about how often a man's semen should be used successfully. In Denmark ${ }^{6}$ the limit is 15 pregnancies, and in Britain a limit of 20 has been tentatively suggested-a figure which seems rather high.

Should AID be more widely available within the National Health Service? At present it is mainly provided by university departments of obstetrics - and by private practitioners, whose fees may be far from nominal. The service is not particularly expensive, but in theory it diverts NHS resources which could have been used for the care of the sick. Potentially about $3 \%$ of the population ${ }^{3}$ could benefit from AID, but until more people know about the service and it has become more widely acceptable the full extent of demand will be impossible to assess.

${ }^{1}$ Royal College of Obstetricians and Gynaecologists, Artificial Insemination. London, RCOG, 1979.

2 Newton, J R, in Artificial Insemination-Proceedings of the Fourth Study Group of the Royal College of Obstetricians and Gynaecologists, ed $\mathrm{M}$ Brudenell et al, p 25. London, RCOG, 1976.

${ }^{3} \mathrm{Kerr}, \mathrm{M} \mathrm{G}$, and Rogers, C, fournal of Medical Ethics, 1975, 1, 30.

4 Ledward, R S, et al, British fournal of Obstetrics and Gynaecology, 1976, 83, 917.

${ }^{5}$ Bromwich, P, Kilpatrick, M, and Newton, J R, British fournal of Obstetrics and Gynaecology, 1978, 85, 641 .

${ }^{6}$ Hansen, K B, Nielsen, N C, and Rebbe, H, British Fournal of Obstetrics and Gynaecology, 1979, 86, 384.

${ }^{7}$ Friedman, S, Fertility and Sterility, 1977, 28, 1230.

${ }^{8}$ Macourt, D C, and Jones, G R, Medical Fournal of Australia, 1977, 1, 693.

${ }^{9}$ Dixon, R E, and Buttram, V C, Fertility and Sterility, 1976, 27, 130.

${ }^{10}$ Pennington, G W, and Naik, S, British Medical fournal, 1977, 1, 1327.

11 David, A, and Avidan, D, Fertility and Sterility, 1976, 27, 528.

12 Strickler, R C, Keller, D W, and Warren, J C, New England fournal of Medicine, 1975, 293, 848.

${ }^{13}$ Klay, L J, Fertility and Sterility, 1976, 27, 383.

14 Jennings, R T, Dixon, R E, and Nettles, J B, Fertility and Sterility, 1977, 28, 554 .

${ }^{15}$ Horne, H W, New England Fournal of Medicine, 1975, 293, 873.

16 Beck, W W, Fertility and Sterility, 1976, 27, 1.

17 Kraus, J, and Quinn, P E, Medical fournal of Australia, 1977, 1, 710.

18 British Kedical fournal, 1975, 4, 2.

\section{Pyomyositis}

A recent review from Nigeria $^{1}$ reminds us that, while pyomyositis is mainly a disease of the tropics and subtropics, it may also be seen in Europe. The muscles most commonly affected are those in the gluteal or quadriceps group, but any large muscle may be infected. Usually the first symptoms are pain in the affected muscle, followed within the next week by fever, localised induration, and oedema. A minor degree of leucocytosis and eosinophilia (about $10 \%$ ) is commonly present at this stage.

Symptoms gradually progress, so that between 10 and 20 days after the onset the muscle mass is definitely oedematous and tender. At this stage aspiration of the muscle will yield pus, which usually produces a growth of Staphylococcus aureus. If no effective treatment is given, the infection will progress until finally the whole muscle is destroyed and replaced by a bag of pus. The muscle abscesses are often multiple, and occasionally there may be evidence of more disseminated pyogenic infection 